Another volume asserts that consumption may be caused by putting on spring clothing too early in the season! One also reads that cider-drinkers are peculiarly crabbed and cross, that tobacco makes old men illnatured, that sour milk is unwholesome, cheese is indigestible, pork is a meat not fit to eat, and bile has the properties of baking: soda? Here is a fish story told in the words of a highly commended book: "The Esquimaux who live in Greenland, drink one or two quarts of oil, and eat several pounds of candles every day!" But see how a story will "grow" even in a scientific text-book. In the next number of the "series" written by the same author, and from the same reliable notes, doubtless, we read, "An Esquimaux consumes about twenty pounds of blubber fat daily, besides drinking several quarts of train oil." What it will be in the next volume, who can tell?

As to the style and accuracy of these "scientific" treatices, the following may be taken as samples: "The eyeball is a bag (!) almost round, thick and dull everywhere but in front, where it has a transparent covering called the cornea, meaning a horn. This is fitted into the eye just as a watch-crystal is fitted into a watch."! How lucid and true, now proceed, "The back chamber" (of the eye) "also holds a jelly-like fluid, called the 'glassy humor,' which allows the iris-curtain to float and move freely." Who don't understand that much at least?

Another matter in connection with these physiologies should receive attention. Many of them contain a statement, printed in a prominent manner in the first portion of the book, that they contain " $a$ fyll and fair treatmant of the nature and effects of alcoholic drinks and other narcotics in connection with relative Physiology and Hygiene." When the books are examined, however, the "full and fair treatment" dwindles into statements true and imaginary, of the evil effects of alcohol on the body. There is no effort at all made to discuss the different effects of large and small doses, of the effects on a full and on an empty stomach, of individual idiosynerasies and not a word of the beneficial effects of alcohol and narcotics when properly used. There can be no doubt but this unfair, unscientific and untruthful manner of presenting this subject is having an effect, exactly the reverse to that which is intended. Children will soon find out that they have been deceived, and the result will be worse than if nothing had been said at all on the subject.

The strictures here noted apply to the books used in the public schools, and to a very limited extent to those used in academies and colleges.

\section{BIRDS OF RARE OCCURRENCE IN NORTHERN}

\section{COLORADO.}

BY WM. OSBURN, NASHVILLE, TENN.

Colorado is prolific in bird life. There the eastern and western forms converge. There mountain, valley, woodland, lake and barren plain, contribute their peculiar species, thus furnishing to the student a field most varied. When observers have completed the record, their labors will probably show a list approaching four hundred species and varieties.

During the years 1888, 1889 and $1890 \mathrm{I}$ had opportunity to study the avi-fauna of a small section of the State. My field of observation was Larimer County, with Loveland, Colorado, as headquarters. Loveland is about seventy-five miles north of Denver, in the midst of a rich farming section, with the foothills some six miles to the west and the open plains a few miles east. During the period named two hundred and forty-one species and varieties were observed. All but a very few of these were actually taken in the field; their skins were preserved, and such data recorded as sex, measurements, color of iris, contents of stomach, etc. From this list I have selected ten birds which to me proved of unusually rare occurrence. Their enumeration may be of interest to other observers. It is not improbable that a few of these have hitherto escaped observation in the locality named and contiguous parts.

Micropalama hımantopus. Stilt Sandpiper. Occasionally met with during the spring migration, in May and early June.

Pediocaetes phasianellus campestris. Prairie Sharp-tailed Grouse. This bird was formerly quite abundant.

Accipiter atricapillus. American Goshawk. A male of this species was captured on February 26, 1889, at Arkins, Colorado. A female was taken in the same locality on March 5. The male was much darker than the female, and with finer markings on the under parts, answering to the description of variety striatulus. Mr. Wm. G. Smith, a careful observer of birds, reported at the time that he had not seen a specimen of this hawk during five years residence. In his "Key to North American Birds" Dr. Elliott Coues says: "It breeds in mountainous regions as far south at least as Colorado, where I have seen it in summer.

Bubo virginianus arcticus. Arctic Horned Owl. A fine Horned Owl, which I have referred to this variety, was shot in the mountains and brought to me on Nov. 29, 1890. It was nearly white. A dissection revealed a large tape-worm in the back, above the intestines.

Colaptes auratus. Flicker. A typical Flicker was taken during the fall migration, September 24, 1889. While the hybrid form, exhibiting every conceivable gradation between auratus and cafer, is quite abundant, yet a typical auratus is seldom observed.

Scolecophagus carolinus. Rusty Blackbird. One specimen was taken in November, 1889. No other observation recorded.

Zonotrichia coronata. Golden-crowned Sparrow. Concerning the habitat of this species, Dr. Coues makes the following record: "Pacific coast (to Rocky Mountains?) from Alaska to Southern California." A small flock of these birds spent the winter of 1889 in a thicket along the Big Thompson. They were associated with Intermediate Sparrows. One specimen was taken on February 23.

Dendroica gracioe. Grace's Warbler. During the spring migration of 1889 a small flock of this species was seen near the foothills. One specimen, taken April 25, is in the writer's possession.

Cistothorus palustris. Long-billed Marsh Wren. Two specimens were taken in March, 1889. Its occurrence is apparently not common.

Among others collected, the following may be named as more common than the preceding, yet only met with occasionally: Golden crowned Kinglet, Wilson's Warbler, White-throated Swift, Cedar Waxwing, Slate-colored Junco, House Finch, Arizona Goldfinch, Pallid Horned Lark, Woodhouse's Jay, Hammond's Flycatcher, Alpine Three-toed Woodpecker, Pigmy Owl, Prairie Falcon, Richardson's Merlin and American Golden Plover.

_.Our Own Birds," by Wm. L. Bailey, published by J. B. Lippincott Company, is an excellent little manual for those who wish to become familiar with the common birds of this country. It contains a number of half-tone fullpage illustrations, with others in the text. 